\title{
Examining Retailing Sustainability in the QR Code-Enabled Mobile Payments Context During the COVID-19 Pandemic
}

Hawazen Alamoudi, College of Business, Marketing Department, King Abdulaziz University, Rabigh, Saudi Arabia

\begin{abstract}
COVID-19 has influenced customer purchasing behavior, especially the acceptability of mobile payments based on quick response $(\mathrm{QR})$ codes. Sustainability is key for retail to thrive. In this context, customer acceptance of QR code-enabled m-payments needs further improvement. This study examines the critical antecedents affecting QR code-enabled m-payments acceptance intention, with the aim of determining why customers must accept QR codes. The mobile technology acceptance model was modified, as the authors examined ease of use, usefulness, transaction convenience, transaction speed, attitudes, optimism, and personal innovativeness to investigate customers' adoption of mobile shopping in grocery stores using questionnaire survey data of 351 respondents. Most constructs in the model influence shoppers' intentions for accepting QR code-enabled m-payments. Consumers are more likely to use mobile shopping channels if the system is simple and easy to use. A validated model would be an invaluable guide for researchers during the creation and improvement of QR code-enabled m-payments studies.
\end{abstract}

\section{KEYWORDS}

COVID-19 Pandemic, Mobile Payments, Mobile Technology Acceptance Model, QR Code, Retailing Sustainability

\section{INTRODUCTION}

The Build Back Better strategy and the effect of the "new normal" has greatly influenced today's customers' purchasing behavior as well as retailing. This necessitates adoption of a good strategy to accomplish Goal 12 of the sustainable development goals - sustainable consumption and productionto sustainably cover the needs of firms and customers. A sustainably produced product or service will meet fundamental needs while minimizing consumption to avoid compromising the future needs of future generations, while keeping the emissions of waste and pollutants to a minimum (UN, 2030). Nowadays, food consumption tends to be a primary requirement for people globally; therefore, retailers must meet consumers' demands with great care. To link customer demands with production, technology may be used to simplify buying procedures, which can help manage shopping habits and consumption. Customers prefer to shop at their grocery store, utilizing technologies as they desire simplicity and convenience when they shop (Nielsen, 2018). Therefore, there are several technological avenues to swiftly and securely complete their shopping (Walker, 2018). For example, Tesco's South Korean subsidiary, Home Plus, established virtual stores around subway stops. The layout of these virtual storefronts is identical to that of a physical store. Customers may scan a quick response (QR) code to order items, which would subsequently be dispatched within hours. Furthermore, there is a 
significant possibility that growth in technological models, which also integrate smartphones, will provide the best individualized internet shopping experience in the future (Walker, 2018). Considering the rising relevance of retail, a number of retailers have begun selling their goods on various platforms (Zhang et al., 2010). In Saudi Arabia, particularly, the Saudi Press Agency, under the Ministry of Commerce and Investment, has approved the electronic service "Your QR Code," which is anticipated to boost the credibility of commercial enterprises by providing information about the commercial register and associated government agencies. However, the usage of QR code continues to be limited. Recently, Saudi Arabia's cabinet announced licenses for two digital banks; Saudi Telecom's STC Pay business will transform into a digital bank with a capital of 2.5 billion Riyals ( $\$ 666.7$ million). One possible explanation for this decision could be the government's initiatives to move towards a cashless society. Across the Gulf countries, digital payments and banking are currently growing in popularity (Somro, 2019). As a result of the growth of digital technologies and web-based businesses, diverse industries have launched online platforms on the retail market to round out their online store/in-store investment portfolio. The gradual but rapid shift to mobile phones has re-engineered consumers' interaction with several aspects of daily life, thereby opening up new market potential in a variety of industries (Chao et al., 2013). Both these goals (Goal 12 of SDG and Saudi Vision 2030) indicate the necessity of elucidating the drivers of QR code m-instalment collection as the community strives to shift to a payment economy. The Saudi Central Bank has authorized High-tech Payment Systems, a payments technology and logistics company, to provide the QR code-based payment mechanism (SAMA)(Fintech future:written by Alex Hamilton 6th March 2020). Besides recognizing different payment structures, the system can also store information in a static QR code, which could be used for various exchanges, or in a special QR code for preparing instalments. Despite the many focal points of m-shopping, in Saudi Arabia, its usage remains poor, coupled with a lack of clarity among Saudi buyers regarding this channel. This research explores the variables that affect customer intentions to accept QR code-enabled m-payments. Some studies predict the acceptance of QR code-enabled $\mathrm{m}$-payments, but there is no solid understanding of the factors that influence their intentions in the context of a developing economy, such as Saudi Arabia; therefore, the Mobile Technology Acceptance Model (MTAM) has been applied in this study. This study also involved a survey of m-payments literature from the perspective of developing nations, as well as a testing of the robustness of the MTAM model, as it only involves two constructs. Despite there being considerable potential for m-payment to disrupt several sectors (e.g., Retailing, Banking, Utilities, Transportation, Consumer electronics, etc.), there is an undiscovered potential for its future applications in Saudi Arabia, due to low usage (Alqahtani et al., 2014). To promote adoption of new technology in Saudi Arabia's banking sector, several studies were conducted in the context of banking intentions of Gulf consumers (Alqahtani, Al-Badi, \& Mayhew, 2014; Halaweh \& Al Qaisi, 2016; Manochehri \& AlHinai, 2008; Musa, Khan, \& AlShare, 2015; Rouibah, 2007, 2009; Sharma, Sharma, \& Dwivedi, 2019). The topic of m-payments was the most researched topic among these studies (Alkhowaiter, 2021). Generally, literature review provides knowledge that guide different stakeholders, such as governmental entities and corporate executives. In addition, past investigations which investigated m-payment were mostly drawn closer from a general point of view. This research focuses on $\mathrm{QR}$ code-enabled m-payments due to its low prevalence in Saudi Arabia. Additionally, various technologies such as near-field communication (NFC), QR codes, and others have become commonplace today (de Luna et al., 2019). As service providers produce more sophisticated features, applications, and services, they must be aware of the factors influencing consumer intentions, so they can lead $\mathrm{m}$-shopping deployment strategies, marketing campaigns, and information dissemination. This results in favorable linkages between service providers and customers in an m-shopping environment.

Section 2 presents the literature review and hypotheses. The research methodology and results are discussed in Section 3, followed by a discussion of the findings in Section 4. Limitations and future research avenues are discussed in Section 5. 


\section{LITERATURE REVIEW AND HYPOTHESES DEVELOPMENT}

\section{Mobile Technology Acceptance Model (MTAM)}

David Davis (1989), developed the Technology Acceptance Model (TAM), applying it to examine the antecedent factors that affect people's intentions to accept modern technology. It is not one of the most extensively and commonly used models while analyzing intentions to adopt disruptive technology (Alharthi et al., 2021; Kamal et al., 2020; Shaikh et al., 2020; Alalwan et al., 2018) in the light of its simplicity of theoretical basis (Chang et al., 2016). This is a concern as the adoption of technology across the workplace differs in a variety of ways, such as the styles and intricacy of activities (Brown et al., 2006). Researchers Ajzen and Fishbein (1980) and Ajzen (1991) have developed theories of a human response to new technology, namely the Theory of Reasoned Action (TRA) and the Theory of Planned Behavior (TPB). These two theories have been widely used in the study of the adoption and use of different information technologies. It was revealed by Yang et al. (2012) that a person's willingness to accept an innovation is determined by his or her attitude and subjective norms. These norms are created by an individual's behavior and normative views. According to TAM, perceived usefulness (PU) and ease of use (PEOU) are factors that determine a person's attitude towards the use of a specific technology, which consequently determine the intended use of that technology (Davis 1989). Additionally, electronic and mobile settings require different responses from users. Mobile users may perceive ease of use differently from desktop users in relation to battery life and screen size (Tan et al., 2014). Recently, it was determined that TAM fared quite poorly than revolutionary technologies in changing the intentions and behaviors of users (Legris, 2003).

Ooi and Tan (2016) asserted that the original TAM system was inefficient and failed to incorporate disruptive technologies. Thus, they developed a larger model called MTAM. A study was conducted to explore how smartphone credit cards are adopted by examining several variables, including perceived usefulness (PU) and perceived ease of use (PEOU). Additionally, numerous academics have referenced variables from other relevant disciplines in the context of mobile technology (Ooi and Tan 2016). According to TAM, IT use depends on attitudes towards innovations, which subsequently influences intentions to use them. TAM predicts individuals' rationality in their decision-making processes when they adopt new technologies (Venkatesh et al., 2012). Positive experiences and performances associated with $\mathrm{m}$-shopping will encourage consumers to future adoption and use (Davis, 1993). This seems to be a question of applicability, since many consumers respond differently to electronic and smartphone setups. For example, the expected ease of use of smartphone devices will be different from those using personal PCs when it comes to battery capacity and window display (Tan et al., 2014). However, modifying the intentions of shoppers to evaluate the effect of various retail innovations on shoppers' expectations (Inman and Nikolov, 2017) requires other factors to be considered critical to the effect of TAM (Luarn and Lin, 2005). According to previous studies Phan and Daim (2011), as well as Benbasat and Barki (2007), in order to address this limitation, more variables would need to be added to the model so that we can gain a greater understanding of the antecedents affecting the implementation of emerging technologies, particularly mobile devices. Another study in Singapore used TAM with PU, PEOU, and attitudes to examine factors that affect mobile commerce adoption (Yang, 2005). Thus, incorporating variables from TPB into TAM is expected to provide a comprehensive understanding of consumer adoption intentions of $\mathrm{m}$-shopping. A variety of other factors should be considered in mobile contexts (Kim et al., 2010; Chen, 2008). An extended MTAM approach in the present study that incorporates other relevant factors in order to gain a comprehensive understanding of the antecedents influencing m-payment adoption intention. These antecedents of m-payment adoption intention and their extended model are significant advances in the current academic literature on mobile technology acceptance. An integrated approach involving MTAM, TPB, and Personal Innovation (PI) was developed to study m-shopping adoption intention among Saudis, which has heavily influenced m-payment literature, both theoretically and practically. Moreover, an empirical study in Saudi Arabia examined the factors affecting customers' 
intentions towards m-shopping. A uniquely extended MTAM was used to investigate the antecedents impacting m-payment acceptance intentions. This included additional relevant variables for a more comprehensive investigation. Its novel findings and the extended model proposed therein represent significant innovations in mobile technology acceptance research. Researchers will also be able to create more complete theoretical models if they understand the elements influencing customers' intentions to use m-commerce in emerging economies. As a result, the MTAM works well for this research since the nature of the study is quite comparable to the original circumstance for which it was created. It requires a multidisciplinary approach to develop effective acceptance estimates (Tan et al., 2014; Leong et al., 2013). In an attempt to gain insights on QR code-enabled m-payments, the MTAM was modified by incorporating important factors such as perceived transaction convenience (PTC), perceived transaction speed (PTS), optimism (OP), and personal innovation (PI), in addition to the factors of behavioral intention (BI) and attitudes (ATT).

The proposed MTAM framework has been depicted in Figure1.

\section{Hypotheses Development}

The conceptual model as depicted in Figure 1 indicates a number of hypothesized relationships namely, impact of perceived usefulness and perceived ease of use on attitude; of perceived transaction convenience on perceived usefulness; of Perceived transaction speed on perceived ease of use; of attitude on behavioral intention; of optimism on behavioral intention; and of personal innovativeness on behavioral intention.

Perceive usefulness on attitude

M-payments improve individuals' transactional performance (Kaatz, 2020; Ooi and Tan, 2016). Customers are more willing to adopt new technology if they believe the activities connected with it would improve their performance (Mallat, 2007; Vijayasarathy, 2004). Chuah et al. (2016) showed that usefulness is a major factor driving smartwatch adoption. A study on the acceptance of e-learning in a high-tech firm as well as an online survey in Korea found that perceived usefulness positively affects behavioral intention (Ho Cheong and Park, 2005; Ong et al., 2004). Additionally, the evidence suggests that usefulness has a significant impact on behavioral intention to adopt m-payment systems in Gulf countries as well (Alkhowaiter, 2020). In Saudi Arabia, Alqahtani et al. (2014) found that mobile usefulness significantly impacts the behavioral intention to adopt m-payments. The shopping experience is believed to be impacted by attitude because m-shopping has no physical constraints as it is not constrained by time or location. There is consistent evidence that perceived usefulness affects consumers' attitudes toward IT, and thus the following hypothesis is proposed:

H1. Perceived usefulness has a positive relationship with consumers' attitudes towards QR codeenabled m-payments acceptability.

Perceived ease of use on attitude

Consumers' perceived ease of use of a mobile device's ease of use can be measured by how well it is used for shopping online and how effectively and easily it can be used for any service. As any emerging technology is perceived to be more useful if it is easy to use, perceived usefulness is also impacted by perceived ease of use (Venkatesh and Davis, 2000). Customers utilizing mobile shopping platforms have easily accomplished their shopping target (Yang, 2010). It is perceived by shoppers as being user-friendly, which in turn enriches their shopping experience (Yang, 2010). Many researchers have found that perceived ease of use and perceived usefulness favorably influences attitudes (Chen, 2008; Kim et al., 2010; Van der Heijden et al., 2003; Wang et al., 2003). Consumers must be able to easily understand and use QR code m-payments before being able to accept it. Therefore, the hypothesis below has been proposed: 
H2. Perceived ease of use has a positive relationship with consumers' attitudes towards QR codeenabled m-payments acceptability.

Perceived transaction convenience on perceived usefulness

Perceived transaction convenience is a measure of how many individuals consider QR codeenabled m-payments to improve their trust in the transaction process (Chen, 2008; Boden et al., 2020). Cash and credit/debit cards will likely be replaced by an m-payment service (Rampton, 2017). The m-payment facility allows customers to deposit and use multiple card accounts, which means they do not have to carry cash or multiple plastic cards. Numerous studies have demonstrated that perceived transaction convenience is a significant factor influencing m-payment utilization (De Kerviler et al., 2016; Chen \& Nath, 2008). Perceived usefulness of m-payments can be influenced by convenience, which in turn influences the intention to use it. Most customers are expected to examine the QR code and verify that the transaction is authorized by their $\mathrm{m}$-payment system. Therefore, the hypothesis below has been proposed:

H3. Perceived transaction convenience has a positive relationship with perceived usefulness.

Perceived transaction speed on perceived ease of use.

According to Chen (2008), perceived transaction speed is the degree to which individuals can improve their transaction speeds through QR code m-payments. Users will be able to carry out the payment process faster using QR codes, contributing to convenience of use. Studies have found a significant correlation between ease of use of m-payments in Malaysia and perceived transaction speed (Yan et al., 2021; Teo et al. 2015). Notably, ease of use is associated with the intention to approve $\mathrm{m}$-payments. The underlying rapid response technology makes QR code-enabled m-payments different, which ultimately helps in decision-making about payments. Individuals with a mobile device can make payments using QR codes by approaching a compatible terminal. There has been a lot of interest in this technology, especially since it is user-friendly (Luna et al., 2019). Therefore, the following hypothesis has been proposed:

H4. Perceived transaction speed has a positive relationship with perceived ease of use.

Attitude on intention

A person's attitude towards performance is defined as their positive or negative feelings (Davis et al., 1989; Fishbein \& Ajzen, 1977). In an online environment, attitudes are expected to facilitate transactions and reduce barriers to the adoption of terms of trade (Pavlou, 2002a; Pavlou, 2002b), which in turn could increase intentions to use m-payment systems (Schierz et al., 2010). Attitudes have been found to influence behavioral intention (Dwivedi et al., 2019; Chavali \& Kumar, 2018; Sharma et al., 2015). Yang (2012) found that an individual's attitude was a significant determinant of consumer characteristics underlying adoption of mobile shopping. Nevertheless, multiple studies have shown that attitudes and utilization are linked (Liébana-Cabanillas et al., 2015; Chen and Chang 2013; Lee and Ryu 2013; Meharia 2012; Hansen, Risborg, and Steen 2012; Liébana-Cabanillas 2012;). In addition, attitudes towards mobile shopping are also likely to influence consumer decisions to participate in mobile shopping. The study suggests a strong relationship between payment systems and the emerging economy as previously published (Tsai et al., 2010). Therefore, the hypothesis below has been proposed:

H5. Consumers' attitude toward adopt m-shopping positively influences intention to accept QR code-enabled m-payments. 
Optimism on behavioral intention

Optimism refers to a positive image of technology among consumers, which promotes efficiency and versatility and influences people to use creative technology (Parasuraman, 2000; Parasuraman and Colby, 2015 Parasuraman, 2000;). Technology optimism—consumers' belief in new technologyimpacts users by enhancing consumption of technology-based goods and services. Technology acceptance researcher Davis (1989) posited that perceived usefulness (utilitarian benefits) in conjunction with perceived ease of use was a crucial predictor of technology adoption in TAM. Earlier studies in developed and developing countries have found that optimism and innovation promote the consumption of certain technology-based products and services (e.g., Cruz-Cárdenas et al., 2019; Lam, Chiang, \& Parasuraman, 2008). Previous research on AI-powered automated retail stores have found the impact of optimism on usefulness and ease of use to be positive (Pillai et al., 2020; Ali et al., 2015). Despite inconsistent results (Oh et al., 2014; Shin et al., 2014; Kumar et al., 2013), there was a general consensus that optimism led to heightened usability and usefulness for mobile environments. The causal relationship between optimism and m-payment adoption was determined to be positive by Humbani and Wiese (2018). Therefore, the following hypothesis has been proposed:

H6. Optimism has a positive relationship with behavioral intention or the intention to accept QR code-enabled m-payments.

Personal innovativeness on behavioral intention

An individual's willingness to engage in new technologies, including QR code-enabled m-payments, is expressed by their personal innovativeness (Kim et al., 2010; Agarwal and Prasad, 1998). M-shopping and technology integration are more likely to be accepted as opportunities in Saudi Arabia and has been used as a modern shopping platform. As early technology adopters, these users also serve as a channel for peer ideas and innovations (Duane et al., 2014). It is estimated that personal innovativeness influences both the explicit and implicit intentions of customers in their internet shopping behavior (Limayen et al., 2000). According to research conducted by Tan et al. (2014) in Malaysia, and by Slade et al. (2013) in the UK, positive intent predicts optimism in m-payments. Many studies have shown that the power of personal innovativeness is an important factor driving product adoption, yet the theory is rarely included in popular technology acceptance models (Cowart et al., 2008). After all, the results of recent research have confirmed the important positive impact of personal innovation on the intention to adopt m-payment in diverse geographical contexts (Yan et al., 2020; Zhang et al., 2018; Ghazali et al., 2017; Makki et al., 2016; Oliveira et al., 2016; Zarmpou et al., 2012). A UK-based study explored how antecedents affect non-users' adoption intentions of m-payments (Slade et al., 2015). Therefore, the following hypothesis has been proposed:

H7. Personal innovativeness has a positive relationship with behavioral intention to accept QR code-enabled m-payments.

\section{RESEARCH METHODOLOGY}

This study targeted mobile shopping users of grocery retail shopping in Saudi Arabia. Nowadays, the increasing rate of smartphone usage has gradually influenced mobile shopping, and the use of a mobile phone is the subject matter of this study. Moreover, during the COVID-19 pandemic, Saudi consumers increasingly adopted technology to facilitate their everyday needs. However, online shopping played a vital role in terms of distances between consumers and retailers. Samples were drawn from large supermarket customers in Saudi Arabia, and respondents were specifically selected according to their purchase M-shopping (Chin, 2018). To ensure perceptions were based on direct 
Figure 1. Proposed theoretical model of an extended version of MTAM

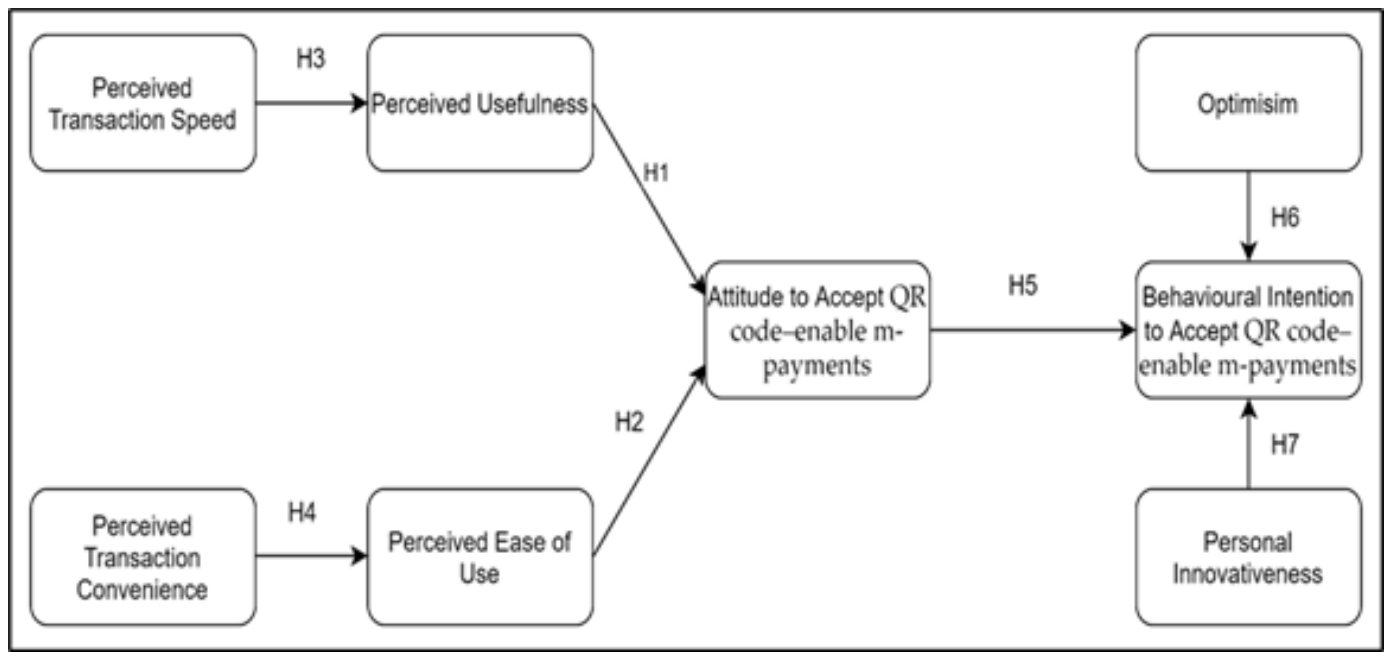

behavioral experiences with the object, only users who purchase through mobile shopping in grocery for the past 12 months were included during analysis. People from various socioeconomic backgrounds visit shopping centers in large numbers (Tan and Ooi, 2018; Wong et al., 2015). The period of data collection was between December 2020 and January 2021. In order to avoid bias in the sample (Hew et al., 2017), a standard of screening was used to select respondents with experience or familiarity with the topic of the present research (Etikan et al., 2016). The questionnaire was administered only to those who consented and had mobile shopping experience in the past 12 months. The questionnaire survey measured responses demographic characteristics between female/male, from age 18 till above 60, and with variant of income scale on a seven-point Likert scale ranging from $1=$ "strongly disagree" to 7 = "strongly agree". Table 1 presents the constructs and measurement items, as well as the studies on which the questionnaire items are based. Partial least squares structural equation modeling (PLS-SEM), which analyses relationships and meanings of various variables, has been found to be a powerful empirical method for investigating the m-shopping environment, which is based on IT (Ghazali et al., 2017). PLS-SEM studies should still be conducted with larger sample sizes than the normal distribution (Kock and Hadaya, 2018), because the higher the number, the better reflects the characteristics of these samples (Vanvoorhis and Morgan, 2007). In total, 439 questionnaires were distributed in the study, of which only 351 were usable. A response rate of $80 \%$ was achieved through this methodology, which is somewhat similar to previous studies on m-payments conducted in Malaysia (Yan et al.2020) and on m-banking conducted in Saudi Arabia (Baabdullah et al.2019) At given power levels and significance levels, the minimal sample size is the number of observations necessary to confirm or deny the existence of a minimum effect in SEM (Westland, 2010). Although the ideal sample size for PLS-SEM analysis is larger than the minimum sample size (Kock and Hadaya, 2018), a larger sample size corresponds with the population characteristics (Vanvoorhis and Morgan, 2007, p.45). To achieve greater generalizability of the findings and cover a wide segment of the Saudi society, data were gathered online questionnaire survey from the western and central cities of the Kingdom of Saudi Arabia. Due to the lack of an address and customer list for Saudi grocery shoppers, convenience sampling was used to collect data through a questionnaire survey. 


\section{RESULTS}

\section{Data Analysis}

\section{Respondents' Characteristics}

According to Table 2, men and women constitute $39 \%$ and $61 \%$, respectively, of the total sample. Most survey respondents were Saudi nationals (80\%), compared to only $20 \%$ of non-Saudi respondents. The respondents primarily belonged to the age group of 31-40 years. In general, most respondents who have shopped at online groceries held a master's degree. Notably, those who were surveyed earned around SAR 12000 monthly (16\%). In terms of using QR code-enabled m-payments in the past 12 months, 36\% indicated that they used them 1-10 times, whereas $24 \%$ indicated that they used them 11-20 times.

\section{Statistical Analysis}

Using SmartPLS version 7.0 (released in 2020), PLS-SEM was used to analyze the structural and measurement models. PLS-SEM has been advocated for complex research models due to its higher prediction accuracy (Yan et al. 2021 and Tan et al. 2018). Additionally, PLS-SEM accommodates data with abnormal distributions. There were 11.260 skewness coefficients in Mardia's multivariate distribution $(p=0.001)$ and 93.01 kurtosis coefficients $(p=0.001)$, which indicated that the data were not normally distributed. PLS-SEM, then, is found to be appropriate. Table 3 presents factor loadings, Cronbach's alpha, composite reliability (CR) and average variance extracted (AVE) for the constructs. All items had loadings greater than 0.5, fulfilling the convergent validity criteria (Bagozzi, 1994). All constructs had acceptable Cronbach's alpha values ( $>0.7)$. This study showed CR ranging from 0.75 to 0.87 , which is acceptable (Fornell and Larcker, 1981). There was a significant difference between the AVEs of the constructs ranging from 0.62 to 0.69 (Fornell and Larcker, 1981). Harman's single-factor test was deployed to measure the bias of methods using common techniques (Podsakoff et al., 2003). There was less than 50\% explanation for the first factor, which accounted for $28 \%$ of the variance. Almost all of the loadings had a significant $t$ value ( $\mathrm{p} 0.01$ ) and a large convergent validity value $(>0.5)$, indicating that the common method bias $(\mathrm{CMB})$ was not a concern for our study. I contrasted the squared root of AVEs with their corresponding correlations (Fornell and Larcker, 1981). to evaluate discriminant validity (Bagozzi, 1994). According to Table 4, the square root of the AVE for each variable exceeds the correlation between the variables, showing adequate validity.

Common method bias (CMB)

The respondents in this study provided all independent and outcome variables, raising questions about the possibility of common method bias (CMB). The study questionnaire design incorporates several procedural remedies, as proposed by Podsakoff et al. (2003), to prevent other common method biases. As a second method of assessing biases, we used the single-factor test developed by Harman. This test confirmed that there was no one general factor or single factor that explained the majority of covariance in the measurements. In addition, a marker variable was used, as in Lindell and Whitney (2001). As the respondents know that they will be asked subsequent questions after they respond to their previous questions, there is a reduced possibility of common method variance. This study reduces the effect of $\mathrm{CMB}$ due to other factors. This involves including knowledgeable respondents and ensuring complete anonymity to respondents.

Assessing the outer measurement model

Composite Reliability (CR) and Cronbach's Alpha were used to measure dependability. Table 3 shows a Cronbach's alpha value greater than 0.88 on average. Thus, all the constructs tested in this study were found to be reliable (Sekaran and Bougie, 2016). Convergent validity has likewise been established since all constructs have AVEs greater than 0.50, and each measurement item has an outer loading greater than 0.80. (Hair et al., 2017).

Inspecting the inner structural model 
Table 1. Constructs, measurement items, and corresponding studies

\begin{tabular}{|c|c|c|}
\hline Constructs & Measurement items & Sources \\
\hline \multirow[t]{4}{*}{ Perceived Usefulness (PU) } & $\begin{array}{l}\text { PU1: Using QR code m-payment improves my } \\
\text { productivity in purchasing. }\end{array}$ & \multirow[t]{4}{*}{ Ooi and Tan (2016) } \\
\hline & $\begin{array}{l}\text { PU2: Using QR code m-payment enhances my } \\
\text { effectiveness in my daily work. }\end{array}$ & \\
\hline & $\begin{array}{l}\text { PU3: Using QR code m-payment makes the handling of } \\
\text { payment easier. }\end{array}$ & \\
\hline & $\begin{array}{l}\text { PU4: Overall, I would find QR code m-payment to be } \\
\text { advantageous. }\end{array}$ & \\
\hline \multirow[t]{4}{*}{$\begin{array}{l}\text { Perceived Ease of Use } \\
\text { (PEOU) }\end{array}$} & $\begin{array}{l}\text { PEOU1: Learning to use QR code m-payment is easy } \\
\text { for me. }\end{array}$ & \multirow[t]{4}{*}{ Ooi and Tan (2016) } \\
\hline & $\begin{array}{l}\text { PEOU2: Using QR code m- payment does not require a } \\
\text { lot of mental effort. }\end{array}$ & \\
\hline & $\begin{array}{l}\text { PEOU3: Interaction with QR code m-payment is clear } \\
\text { and understandable. }\end{array}$ & \\
\hline & $\begin{array}{l}\text { PEOU4: It would be easy for me to become skillful at } \\
\text { using QR code m-payment services }\end{array}$ & \\
\hline \multirow{3}{*}{$\begin{array}{l}\text { Perceived Transaction } \\
\text { Convenience (PTC) }\end{array}$} & PTC1: QR code m-payment is simple and convenient & \multirow[t]{3}{*}{ Teo et al. (2015) } \\
\hline & PTC2: QR code m-payment is always accessible. & \\
\hline & $\begin{array}{l}\text { PTC3: I am able to complete my purchases without } \\
\text { difficulty. }\end{array}$ & \\
\hline \multirow[t]{3}{*}{ Perceived Transaction Speed (PTS) } & $\begin{array}{l}\text { PTS1: I believe that using QR code m-payment will } \\
\text { improve the speed of transaction. }\end{array}$ & \multirow[t]{3}{*}{ Teo et al. (2015) } \\
\hline & $\begin{array}{l}\text { PTS2: Using QR code m-payment helps me to reduce } \\
\text { time spent in shopping. }\end{array}$ & \\
\hline & $\begin{array}{l}\text { PTS3: Compared to traditional payment methods, I } \\
\text { believe that transactions will be fast if I use QR code } \\
\text { m-payment. }\end{array}$ & \\
\hline \multirow[t]{3}{*}{ Optimism (OP) } & $\begin{array}{l}\text { OP1: Technology gives me more control over my daily } \\
\text { life }\end{array}$ & \multirow[t]{3}{*}{ Lu et al. (2011) } \\
\hline & $\begin{array}{l}\text { OP2: Products and services that use the newest } \\
\text { technologies are much more convenient to use. }\end{array}$ & \\
\hline & $\begin{array}{l}\text { OP3: I like the idea of shopping via } \\
\text { technology because I am not limited to } \\
\text { regular means. }\end{array}$ & \\
\hline \multirow[t]{3}{*}{ Personal Innovativeness (PI) } & PI1: I like to experiment with new technology. & \multirow[t]{3}{*}{ Slade et al. (2015) } \\
\hline & $\begin{array}{l}\text { PI2: I would look for ways to try-out with new } \\
\text { technology. }\end{array}$ & \\
\hline & $\begin{array}{l}\text { PI3: Among my peers, I am usually the first to try out } \\
\text { new technology. }\end{array}$ & \\
\hline \multirow[t]{4}{*}{ Attitude (ATT) } & ATT1: Using QR code m-payment is a good idea & \multirow{4}{*}{$\begin{array}{l}\text { Nysveen et al. } \\
(2005), \text { Shih and Fang } \\
(2004) \text {, Goldsmith } \\
(2002),\end{array}$} \\
\hline & ATT2: Using QR code m-payment is wise & \\
\hline & ATT3: Using QR code m-payment is beneficial & \\
\hline & $\begin{array}{l}\text { ATT4: I feel positive about shopping using mobile } \\
\text { devices }\end{array}$ & \\
\hline \multirow[t]{2}{*}{$\begin{array}{l}\text { Behavioral Intention } \\
\text { (BI) }\end{array}$} & $\begin{array}{l}\text { BI1: I intend to increase the use of QR code m-payment } \\
\text { in the future. }\end{array}$ & \multirow[t]{2}{*}{$\begin{array}{l}\text { Tan et al. } \\
(2014)\end{array}$} \\
\hline & $\begin{array}{l}\text { BI2: I intend to use } \mathrm{QR} \text { code } \mathrm{m} \text {-payment when the } \\
\text { opportunities arise. }\end{array}$ & \\
\hline
\end{tabular}


Table 2. Participants' demographic information $(\mathrm{N}=351)$

\begin{tabular}{|c|c|c|}
\hline Variable & $\mathbf{N}$ & Percentage \\
\hline \multicolumn{3}{|c|}{ Gender (GND) } \\
\hline Male $(\mathrm{GND}=1)$ & 137 & $39 \%$ \\
\hline Female $(\mathrm{GND}=2)$ & 213 & $61 \%$ \\
\hline \multicolumn{3}{|l|}{ Nationality } \\
\hline Saudi $(\mathrm{N}=1)$ & 281 & $80 \%$ \\
\hline Non-Saudi $(\mathrm{N}=2)$ & 69 & $20 \%$ \\
\hline \multicolumn{3}{|c|}{ Age } \\
\hline Between 18 and $20(\mathrm{AGE}=1)$ & 27 & $8 \%$ \\
\hline Between 21 and $30(\mathrm{AGE}=2)$ & 72 & $21 \%$ \\
\hline Between 31 and $40(\mathrm{AGE}=3)$ & 113 & $32 \%$ \\
\hline Between 41 and $50(\mathrm{AGE}=4)$ & 79 & $23 \%$ \\
\hline Between 51 and $60(\mathrm{AGE}=5)$ & 43 & $12 \%$ \\
\hline More than $60(\mathrm{AGE}=6)$ & 16 & $5 \%$ \\
\hline \multicolumn{3}{|c|}{ Education (EDU) } \\
\hline Below high school $($ EDU $=1)$ & 7 & $2 \%$ \\
\hline High school $(\mathrm{EDU}=2)$ & 39 & $11 \%$ \\
\hline College degree $(\mathrm{EDU}=3)$ & 61 & $17 \%$ \\
\hline Bachelor's degree $(E D U=4)$ & 113 & $32 \%$ \\
\hline Master's degree $(\mathrm{EDU}=5)$ & 81 & $23 \%$ \\
\hline Doctoral degree $(\mathrm{EDU}=6)$ & 36 & $10 \%$ \\
\hline Professional degree $(\mathrm{EDU}=7)$ & 13 & $4 \%$ \\
\hline \multicolumn{3}{|c|}{ Income (INC) } \\
\hline Below or equal to SAR4000 $($ INC $=1)$ & 39 & $11 \%$ \\
\hline SAR 4001-5000 $(I N C=2)$ & 41 & $12 \%$ \\
\hline SAR 5001-6000 $(\mathrm{INC}=3)$ & 32 & $9 \%$ \\
\hline SAR 6001-7000 $(\mathrm{INC}=4)$ & 50 & $14 \%$ \\
\hline SAR 7001-8000 $(\mathrm{INC}=5)$ & 38 & $11 \%$ \\
\hline SAR 8001-9000 $(\mathrm{INC}=6)$ & 19 & $5 \%$ \\
\hline SAR 9001-10000 (INC = 7) & 20 & $6 \%$ \\
\hline SAR $10001-11000(\mathrm{INC}=8)$ & 32 & $9 \%$ \\
\hline SAR $11001-12000($ INC = 9) & 55 & $16 \%$ \\
\hline SAR 12000 and above $(\mathrm{INC}=10)$ & 24 & $7 \%$ \\
\hline \multicolumn{3}{|c|}{ Frequency (FRQ) } \\
\hline $1-10$ times $(\mathrm{FRQ}=1)$ & 127 & $36 \%$ \\
\hline $11-20$ times $(\mathrm{FRQ}=2)$ & 85 & $24 \%$ \\
\hline 21-30 times $(\mathrm{FRQ}=3)$ & 55 & $16 \%$ \\
\hline $31-40$ times $(\mathrm{FRQ}=4)$ & 49 & $14 \%$ \\
\hline More than 40 times $(\mathrm{FRQ}=5)$ & 34 & $10 \%$ \\
\hline
\end{tabular}


Table 3. Loadings, composite reliability, Cronbach's alpha, and average variance extracted

\begin{tabular}{|c|c|c|c|c|c|c|c|c|c|c|}
\hline Construct/Indicators & $\begin{array}{l}\text { Standard } \\
\text { Loading }\end{array}$ & CR & VIF & Cronbach's $\alpha$ & AVE & Mean & SD & t-statistic & Skewness & Kurtosis \\
\hline $\begin{array}{c}\text { Behavioral intention to accept } \\
\text { QR m-payment (BI) }\end{array}$ & & 0.94 & 2.039 & 0.92 & 0.608 & & & & & \\
\hline BI1 & 0.93 & & & & & 4.40 & 1.02 & 23.40 & -1.29 & 3.28 \\
\hline BI2 & 0.90 & & & & & 5.29 & 1.45 & 27.18 & -0.84 & 1.09 \\
\hline BI3 & 0.89 & & & & & 4.08 & 0.97 & 24.78 & -2.48 & 4.45 \\
\hline BI4 & 0.95 & & & & & 5.70 & 1.43 & 27.41 & -3.06 & 3.21 \\
\hline $\begin{array}{l}\text { Attitude to accept QR } \\
\text { m-payment (ATT) }\end{array}$ & & 0.95 & 1.954 & 0.93 & 0.540 & & & & & \\
\hline ATT1 & 0.89 & & & & & 4.34 & 1.25 & 21.20 & -3.56 & 1.45 \\
\hline ATT2 & 0.93 & & & & & 4.56 & 0.95 & 25.47 & -4.54 & 2.53 \\
\hline ATT3 & 0.91 & & & & & 4.06 & 1.26 & 23.43 & -1.32 & 2.06 \\
\hline ATT4 & 0.94 & & & & & 5.16 & 1.20 & 29.94 & -0.86 & 1.90 \\
\hline Perceived usefulness (PU) & & 0.92 & 2.903 & 0.89 & 0.684 & & & & & \\
\hline PU1 & 0.95 & & & & & 5.40 & 1.02 & 23.25 & -3.20 & 1.29 \\
\hline PU2 & 0.96 & & & & & 6.03 & 1.45 & 29.94 & -1.45 & 1.43 \\
\hline PU3 & 0.90 & & & & & 3.28 & 0.95 & 20.21 & -2.53 & 2.43 \\
\hline PU4 & 0.93 & & & & & 4.59 & 1.49 & 25.90 & -2.43 & 1.90 \\
\hline Perceived ease of use (PEOU) & & 0.95 & 2.108 & 0.93 & 0.572 & & & & & \\
\hline PEU1 & 0.93 & & & & & 5.18 & 1.08 & 28.20 & -3.20 & 1.43 \\
\hline PEU2 & 0.94 & & & & & 6.12 & 0.98 & 30.28 & -1.29 & 2.38 \\
\hline PEU3 & 0.90 & & & & & 4.38 & 1.20 & 25.29 & -3.76 & 2.17 \\
\hline PEU4 & 0.91 & & & & & 3.99 & 0.99 & 23.19 & -2.05 & 2.19 \\
\hline $\begin{array}{l}\text { Perceived transaction } \\
\text { convenience (PTC) }\end{array}$ & & 0.96 & 1.296 & 0.94 & 0.671 & & & & & \\
\hline $\begin{array}{l}\text { PTC1 } \\
\text { PTC2 } \\
\end{array}$ & $\begin{array}{l}0.93 \\
0.90 \\
\end{array}$ & & & & & $\begin{array}{l}4.39 \\
4.98 \\
\end{array}$ & $\begin{array}{l}1.05 \\
1.29 \\
\end{array}$ & $\begin{array}{l}25.39 \\
24.30 \\
\end{array}$ & $\begin{array}{r}-2.19 \\
-3.28 \\
\end{array}$ & $\begin{array}{l}2.06 \\
1.29 \\
\end{array}$ \\
\hline PTC3 & 0.95 & & & & & 3.20 & .89 & 19.24 & -1.28 & 2.18 \\
\hline $\begin{array}{c}\text { Perceived transaction speed } \\
\text { (PTS) }\end{array}$ & & 0.92 & 1.320 & 0.88 & 0.560 & & & & & \\
\hline PTS1 & 0.94 & & & & & 4.29 & 1.06 & 22.39 & -1.27 & 1.85 \\
\hline PTS2 & 0.92 & & & & & 4.89 & 1.26 & 24.07 & -2.10 & 2.10 \\
\hline PTS3 & 0.89 & & & & & 3.02 & 0.91 & 21.11 & -1.56 & 1.27 \\
\hline Optimism (OP) & & 0.94 & 1.895 & 0.92 & 0.624 & & & & & \\
\hline OP1 & 0.90 & & & & & 5.40 & 1.07 & 25.49 & -1.28 & 2.07 \\
\hline OP2 & 0.94 & & & & & 3.29 & 0.96 & 19.03 & -2.90 & 1.28 \\
\hline OP3 & 0.92 & & & & & 6.10 & 1.46 & 28.76 & -1.64 & 1.06 \\
\hline Personal innovativeness (PI) & & 0.93 & 2.081 & 0.91 & 0.590 & & & & & \\
\hline PI1 & 0.92 & & & & & 3.89 & 0.89 & 18.56 & -2.18 & 1.88 \\
\hline PI2 & 0.91 & & & & & 4.07 & 1.05 & 26.30 & -1.26 & 1.07 \\
\hline PI3 & 0.95 & & & & & 4.12 & 1.16 & 27.56 & -1.60 & 2.16 \\
\hline
\end{tabular}

Notes: CR = Composite Reliability; VIF = Variance Inflation Factor; BI = Behavioral Intention; ATT=Attitude to accept QR m-payment; PU = Perceived Usefulness; PEOU = Perceived Ease of Use; PTC = Perceived Transaction Convenience; PTS = Perceived Transaction Speed; OP = Optimism; PI = Personal Innovativeness.

A p-value of 0.05 and less is the level of significance in our study of the inner structural model. Table 5 and Fig. 2 show that except H7, all hypotheses were accepted. Attitude $(\beta=0.61, p<0.001)$ and optimism $(\beta=0.19, \mathrm{p}<0.001)$ are altogether related to the behavioral intentions to embrace $\mathrm{QR}$ code-enabled payment. Moreover, PU $(\beta=0.56, \mathrm{p}<0.001)$ and PEOU $(\beta=0.31, \mathrm{p}<0.001)$ have critical relationship with Att. On the other hand, only personal innovativeness $(p>0.05)$ was unable to influence behavioral intention to accept $\mathrm{QR}$ code-enabled m-payments. This study applied factors to explain $39.2 \%$ of progressions in behavioral intention to adapt QR code-enabled m-payments. 
Table 4. Discriminant validity of the correlations between constructs

\begin{tabular}{|c|c|c|c|c|c|c|c|c|}
\hline \multirow{2}{*}{ Construct } & \multicolumn{7}{|c|}{ Correlations and square roots of AVE } \\
\hline & BI & ATT & PU & PEU & PTC & PTS & OP & PI \\
\hline BI & $\mathbf{0 . 7 7 9}^{\text {a }}$ & & & & & & & \\
\hline ATT & $0.403^{\text {b }}$ & $\mathbf{0 . 7 3 5}$ & & & & & & \\
\hline PU & 0.461 & 0.329 & $\mathbf{0 . 8 2 7}$ & & & & & \\
\hline PEOU & 0.605 & 0.567 & 0.539 & $\mathbf{0 . 7 5 6}$ & & & & \\
\hline PTC & 0.378 & 0.390 & 0.427 & 0.227 & $\mathbf{0 . 8 1 9}$ & & & \\
\hline PTS & 0.327 & 0.556 & 0.521 & 0.450 & 0.327 & $\mathbf{0 . 7 4 8}$ & & \\
\hline OP & 0.430 & 0.377 & 0.610 & 0.621 & 0.418 & 0.319 & $\mathbf{0 . 7 8 9}$ & \\
\hline PI & 0.419 & 0.302 & 0.426 & 0.372 & 0.327 & 0.518 & 0.388 & $\mathbf{0 . 7 6 8}$ \\
\hline
\end{tabular}

a. Composite reliability values are along the diagonal,

b. Correlations, Loadings, composite reliability, Cronbach's alpha, and average variance extracted

Notes: BI = Behavioral Intention; ATT=Attitude to accept QR m-payment; MU = Mobile Usefulness; MEOU = Mobile Ease of Use; PTC = Perceived Transaction Convenience; PTS = Perceived Transaction Speed; OP = Optimism; PI = Personal Innovativeness.

Table 5. Hypotheses testing results

\begin{tabular}{|c|c|c|c|}
\hline Path directions & Standard Path Loadings & T value & Result \\
\hline ATT ® BI & $0.61 * * *$ & 18.037 & Accepted \\
\hline $\mathrm{OP} \circledast \mathrm{BI}$ & $0.19 * *$ & 8.378 & Accepted \\
\hline PI® BI & $0.09 \mathrm{~ns}$ & 2.017 & Rejected \\
\hline PU $®$ ATT & $0.56 * * *$ & 16.398 & Accepted \\
\hline PEU® ATT & $0.31 * * *$ & 12.516 & Accepted \\
\hline PTC $®$ PU & $0.49 * * *$ & 15.405 & Accepted \\
\hline PTS $®$ PEU & $0.02 *$ & 2.183 & Accepted \\
\hline
\end{tabular}

Notes: $\mathrm{BI}=$ Behavioral Intention; ATT=Attitude to accept QR m-payment; MU = Mobile Useful-ness; MEOU = Mobile Ease of Use; PTC = Perceived Transaction Convenience; PTS = Perceived Transaction Speed; OP = Optimism; PI = Personal Innovativeness

Additionally, perceived transaction convenience and perceived transaction speed account for $47.5 \%$ and $36.2 \%$ of the progressions in both usefulness and ease of use, respectively.

\section{DISCUSSION AND IMPLICATIONS}

This study was designed to assess customers' willingness to accept QR code-enabled m-payments following the adoption of $\mathrm{m}$-shopping in grocery stores. The hypothesized results reveal a substantial influence of perceived transaction convenience on perceived usefulness and of perceived usefulness on attitude, supporting $\mathrm{H} 3$ and $\mathrm{H} 1$, respectively. As a result, more customers are more likely to accept QR code-enabled m-payments. The simplicity of usage is one of its benefits. The knowledge regarding information and availability of goods, as well as the ease of paying for those goods, can enable consumers to spend their time more productively. The associations between perceived transaction speed and perceived ease of use are substantial, thereby supporting H4. Moreover, H5 was supported by the finding that attitude had a strong effect on behavioral intention. This is because individuals who experience transaction convenience and speed, usefulness, and ease of use related to QR code- 
Figure 2. Testing of the structural model

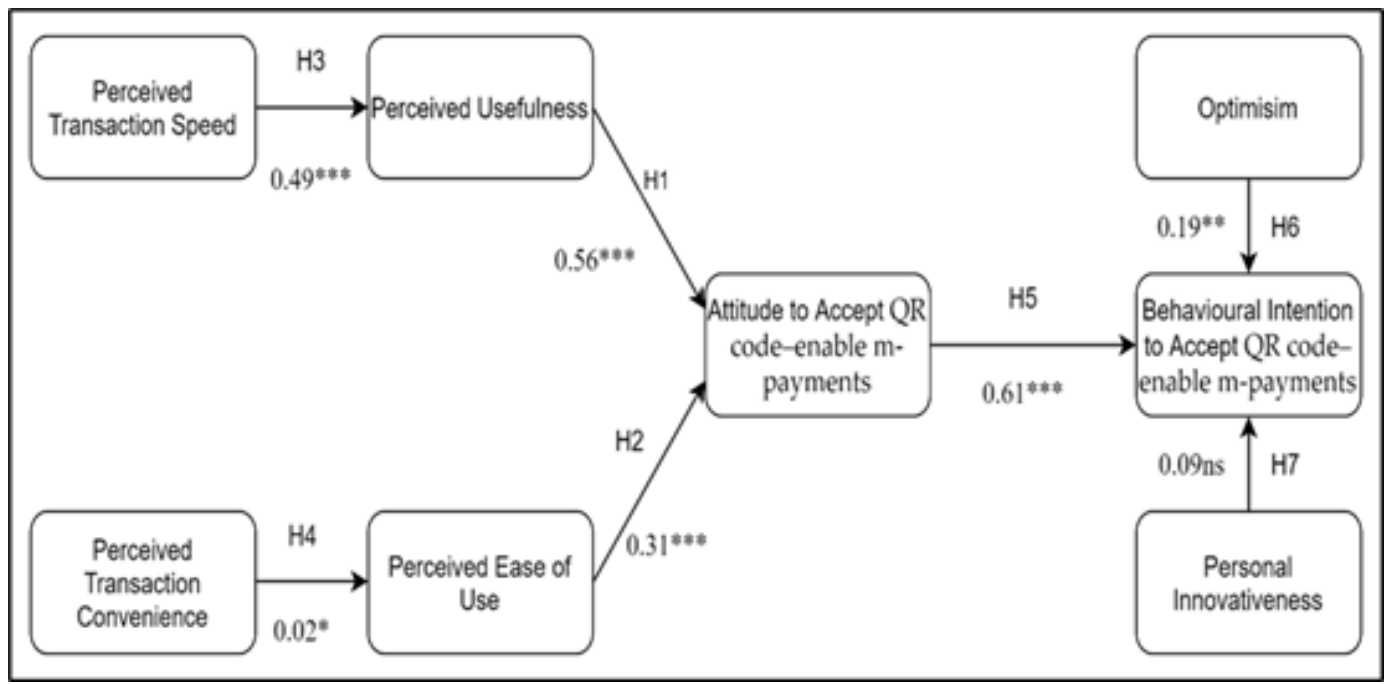

enabled m-payments have positive perceptions regarding its acceptability, which eventually influences behavioral intention. In contrast, $\mathrm{H} 7$ was rejected as personal innovativeness is not significantly related to behavioral intention, which is in line with the findings of (Yan et al. 2021). This could be because all respondents had prior experience with m-payments (Ooi et al., 2011). Therefore, QR code-enabled m-payments may already be perceived as being straightforward and thus not requiring innovation, as opposed to wearable payment modes (Loh et al., 2019). To promote the behavioral intention, service providers and grocery retailers should investigate ways to enhance the usefulness of QR code-enabled m-payments, as well as ensure the ease and speed of related transactions. To achieve positive results from using QR code in grocery retail shops, it needs to be actively used and requires necessary functionalities for serving consumers on time. However, QR codes are not widely used in grocery shopping. Paying at the points of purchase causes a lengthy checkout process because each retail item must be scanned individually. When grocery retailers adopt the self-payment approach using QR codes, customers will be able to scan the QR codes on items and pay for them directly from their $\mathrm{m}$-payment devices, which is a faster and more pleasant checkout procedure. The usefulness and ease of use of QR codes will be enhanced because people have used QR codes to peruse menus at restaurants. Consumers will benefit from enhanced usability and transaction speed. Consequently, the popularity of QR code-enabled m-payments in the retail sector may decrease needless physical contact and ensure adherence to social distancing between individuals during the COVID-19 pandemic (Anderson et al., 2020; Kasab et al., 2020; Wilder-Smith et al., 2020). A new normal was established by the pandemic, wherein restrictions were imposed on all covering various aspects of daily life (Hart, 2020). As part of Saudi Arabia's efforts to keep up with disruptive technological advancements, the government is moving towards a cashless society, which speeds up payment methods by using new disruptive technologies, such as QR codes.

In terms of theoretical contributions, the approach/methodology used in this study was capable of producing informative results. The suggested model incorporates five additional variables, namely perceived transaction convenience, perceived transaction speed, attitude, optimism, and personal innovativeness, in addition to MTAM. The MTAM was expanded based on inputs from many academics (Phan and Daim, 2011; Benbasat and Barki, 2007). Data were collected comprehensively in this study, which has strengthened the credibility of the hypothesis testing. Furthermore, the structural model has a strong predictive relevance based on the $\mathrm{Q} 2$. Due to these findings, this study argues that 
the extended MTAM would be an excellent theory to be applied when analyzing QR code-enabled m-payments acceptance

The findings can be beneficial to marketers and advertisers to integrate QR code-enabled $\mathrm{m}$-payments into their promotional campaigns to increase adoption of mobile shopping. Service providers and authorities may choose to emphasize the benefits of accepting QR code-enabled $\mathrm{m}$-payments to attract more consumers and enhance behavioral intention. This will allow the money flow transactions to continue while also reducing crowd control at the tellers. However, by providing appropriate incentives, more mobile users will be attracted to explore the positive effects of QR code use in m-commerce. Retailers will also be able to reduce overconsumption of groceries by adopting this technology, aligned with Goal 12 of the sustainable development goals. QR code scanning might be beneficial to customers as they can not only make payments, but also gain information about the product. They would feel self-motivated to find out what they want and need. However, the number of grocery store employees will be reduced, which in turn will result in a reduction in retailer expenses. Moreover, this is the first study to introduce the intention to accept QR code-enabled m-payments in Saudi Arabia, which may help decision makers understand the significance of the factors shaping the m-payment infrastructure in Saudi Arabia. Based on the findings of this study, companies can work to improve the attitude of their users towards this technology (for example, by providing information, advertising, promotions, etc.) to increase their willingness to use it. Payment system usage will be improved through these activities, and there would be successful transmission of their usefulness. Companies need to influence the social environment that influences users' buying behavior professionally through appropriate promotional activities in social networks, where users interact faster. Those involved in the promotion of QR code-enabled m-payments technology should also consider other factors, which, despite their minor influence, are still pivotal to the process. Successful adoption of QR code scanning requires promotion by an advertising designer who creates promotions that are perceived as suitable by consumers and that can catch their attention.

\section{LIMITATIONS AND FUTURE RESEARCH AVENUES}

Because this study provides theoretical and managerial implications worth reviewing, it has the following limitation. First, given the Saudi context of this study, the findings may not fully reflect the QR code-enabled m-payments acceptance scenario in other countries, as there is considerable variations globally. In this regard, the findings may not closely reflect contactless payment adoption in other countries. A cross-country study needs to be carried out to expand the scope of the research by incorporating data from multiple countries. Future research may need to consider that in this crosssectional study, respondents' perspectives are only shown from a single point in time. A longitudinal approach may be appropriate for future researchers since it allows comparisons across time. These distinctions may manifest themselves in the form of culture, ethnic groupings, purchasing power, and other factors that may impact technological adoption. As a result, researchers may want to consider incorporating data from increased adoption by shoppers of QR code-enabled m-payments in shopping malls and restaurants, as the QR code is being widely used in the COVID-19 pandemic period for multiple uses. The research then concentrated on QR code m-payment to overcome the shortcomings of previous studies that looked at m-payment from a broader viewpoint. Furthermore, this study recruited only experienced m-payment users, which means that their adoption intention for wearables is more likely to be higher than average. In order to determine if there are any meaningful differences in adoption intention between experienced and inexperienced $\mathrm{m}$-payment users, future researchers should investigate the adoption intention of inexperienced m-payment users. However, alternative options, such as NFC m-payment, are overlooked in this approach. As a result, future researchers may want to consider doing a comparison analysis. 


\section{ACKNOWLEDGMENT}

The project was funded by the Deanship of Scientific Research (DSR) at King Abdulaziz University, Jeddah, under grant no. J: 2-666-1441. The author, therefore, acknowledge with thanks DSR for technical and financial support. 


\section{REFERENCES}

Agarwal, R., \& Prasad, J. (1998). A Conceptual and Operational Definition of Personal Innovativeness in the Domain of Information Technology. Information Systems Research, 9(2), 204-215. doi:10.1287/isre.9.2.204

Ajzen, I. (1991). The theory of planned behavior. Organizational Behavior and Human Decision Processes, 50(2), 179-211. doi:10.1016/0749-5978(91)90020-T

Ajzen, I., \& Fishbein, M. (1980). Understanding Attitudes and Predicting Social Behaviour. Prentice-Hall.

Al Kasab, S., Almallouhi, E., \& Holmstedt, C. A. (2020). Optimizing the Use Of Teleneurology During the COVID-19 Pandemic. Telemedicine Journal and e-Health, 26(10), 1197-1198. Advance online publication. doi:10.1089/tmj.2020.0109 PMID:32329661

Alalwan, A. A., Baabdullah, A. M., Rana, N. P., Tamilmani, K., \& Dwivedi, Y. K. (2018). Examining adoption of mobile internet in Saudi Arabia: Extending TAM with perceived enjoyment, innovativeness and trust. Technology in Society, 55, 100-110. 10.1016/j.techsoc.2018.06.007

Alharthi, M., Shaikh, A., \& Alamoudi, H. (2021). "Your ride has arrived" - Exploring the nexus between subjective well-being, socio-cultural beliefs, COVID-19, and the sharing economy. Telematics and Informatics, 63, 101663. doi:10.1016/j.tele.2021.101663

Ali, H., Ali, T., Matar, Z., \& Jawad, F. (2015). Citizens' Acceptance and Readiness towards Adopting E-Participation Tools in Kingdom of Bahrain. International Journal for Infonomics, 8(2), 1029-1036. doi:10.20533/iji.1742.4712.2015.0121

Alkhowaiter, W. A. (2020). Digital payment and banking adoption research in Gulf countries: A systematic literature review. International Journal of Information Management, 53(102102), 102102. doi:10.1016/j. ijinfomgt.2020.102102

Alqahtani, M. A., Al-Badi, A. H., \& Mayhew, P. J. (2014). Exploratory Study of M-Transaction: User's Perspectives. The Electronic Journal on Information Systems in Developing Countries, 60(1), 1-22. doi:10.1002/j.1681-4835.2014.tb00428.x

Anderson, R. M., Heesterbeek, H., Klinkenberg, D., \& Hollingsworth, T. D. (2020). How will country-based mitigation measures influence the course of the COVID-19 epidemic? Lancet, 395(10228), 931-934. doi:10.1016/ S0140-6736(20)30567-5 PMID:32164834

Baabdullah, A. M., Alalwan, A. A., Rana, N. P., Patil, P., \& Dwivedi, Y. K. (2019). An integrated model for m-banking adoption in Saudi Arabia. International Journal of Bank Marketing, 37(2), 452-478. doi:10.1108/ IJBM-07-2018-0183

Bagozzi, R. P. (Ed.). (1994). Principles of Marketing Research. Blackwell.

Benbasat, I., \& Barki, H. (2007). Quo vadis TAM? Journal of the Association for Information Systems, 8(4), 211-218. doi:10.17705/1jais.00126

Boden, J., Maier, E., \& Wilken, R. (2020). The effect of credit card versus mobile payment on convenience and consumers' willingness to pay. Journal of Retailing and Consumer Services, 52(101910), 101910. doi:10.1016/j. jretconser.2019.101910

Brown, S. A., Venkatesh, V., \& Bala, H. (2006). Household Technology Use: Integrating Household Life Cycle and the Model of Adoption of Technology in Households. The Information Society, 22(4), 205-218. doi:10.1080/01972240600791333

Chang, I-C., Chou, P.-C., Yeh, R. K.-J., \& Tseng, H.-T. (2016). Factors influencing Chinese tourists' intentions to use the Taiwan Medical Travel App. Telematics and Informatics, 33(2), 401-409. 10.1016/j.tele.2015.09.007

Chao, C.-W., Reid, M., \& Mavondo, F. (2013). Global consumer innovativeness and consumer electronic product adoption. Asia Pacific Journal of Marketing and Logistics, 25(4), 614-630. doi:10.1108/APJML-02-2013-0025

Chavali, K., \& Kumar, A. (2018). Adoption of Mobile Banking and Perceived Risk in GCC. Banks and Bank Systems, 13(1), 72-79. doi:10.21511/bbs.13(1).2018.07 
Chen, K.-Y., \& Chang, M.-L. (2013). User acceptance of "near field communication" mobile phone service: An investigation based on the "unified theory of acceptance and use of technology" model. Service Industries Journal, 33(6), 609-623. doi:10.1080/02642069.2011.622369

Chen, L.-D., \& Nath, R. (2008). Part of the Management Information Systems Commons Recommended Citation Recommended Citation Chen. Journal of International Technology and Information Management Journal of International Technology and Information Management, 17(1). https://scholarworks.lib.csusb.edu/ cgi/viewcontent.cgi?article $=1105 \&$ context $=$ jitim

Chuah, S. H.-W., Rauschnabel, P. A., Krey, N., Nguyen, B., Ramayah, T., \& Lade, S. (2016). Wearable technologies: The role of usefulness and visibility in smartwatch adoption. Computers in Human Behavior, 65, 276-284. 10.1016/j.chb.2016.07.047

Cowart, K. O., Fox, G. L., \& Wilson, A. E. (2008). A structural look at consumer innovativeness and selfcongruence in new product purchases. Psychology and Marketing, 25(12), 1111-1130. doi:10.1002/mar.20256

Cruz-Cárdenas, J., Zabelina, E., Deyneka, O., Guadalupe-Lanas, J., \& Velín-Fárez, M. (2019). Role of demographic factors, attitudes toward technology, and cultural values in the prediction of technology-based consumer behaviors: A study in developing and emerging countries. Technological Forecasting and Social Change, 149(119768), 119768. doi:10.1016/j.techfore.2019.119768

da Chen, L. (2008a). A model of consumer acceptance of mobile payment. International Journal of Mobile Communications, 6(1), 32. doi:10.1504/IJMC.2008.015997

da Chen, L. (2008b). A model of consumer acceptance of mobile payment. International Journal of Mobile Communications, 6(1), 32. doi:10.1504/IJMC.2008.015997

Davis, F. D. (1989). Perceived Usefulness, Perceived Ease of Use, and User Acceptance of Information Technology. Management Information Systems Quarterly, 13(3), 319-340. doi:10.2307/249008

Davis, F. D. (1993). User acceptance of information technology: System characteristics, user perceptions and behavioral impacts. International Journal of Man-Machine Studies, 38(3), 475-487. doi:10.1006/imms.1993.1022

de Kerviler, G., Demoulin, N. T. M., \& Zidda, P. (2016). Adoption of in-store mobile payment: Are perceived risk and convenience the only drivers? Journal of Retailing and Consumer Services, 31, 334-344. 10.1016/j. jretconser.2016.04.011

de Luna, I. R., Liébana-Cabanillas, F., Sánchez-Fernández, J., \& Muñoz-Leiva, F. (2019). Mobile payment is not all the same: The adoption of mobile payment systems depending on the technology applied. Technological Forecasting and Social Change, 146, 931-944. 10.1016/j.techfore.2018.09.018

Duane, A., O'Reilly, P., \& Andreev, P. (2012). Realising M-Payments: Modelling consumers' willingness to M-pay using Smart Phones. Behaviour \& Information Technology, 33(4), 318-334. doi:10.1080/0144929X.2012.745608

Dwivedi, Y. K., Rana, N. P., Jeyaraj, A., Clement, M., \& Williams, M. D. (2017). Re-examining the Unified Theory of Acceptance and Use of Technology (UTAUT): Towards a Revised Theoretical Model. Information Systems Frontiers, 21(3), 719-734. doi:10.1007/s10796-017-9774-y

E-payment system for all retailers comes into force. (2020, August 25). Saudigazette. https://saudigazette.com. sa/article/597069

Etikan, I. (2016). Comparison of Convenience Sampling and Purposive Sampling. American Journal of Theoretical and Applied Statistics, 5(1), 1. doi:10.11648/j.ajtas.20160501.11

Fishbein, M., \& Ajzen, I. (1977). Belief, Attitude, Intention and Behavior: An Introduction to Theory and Research. Contemporary Sociology, 6(2), 244. doi:10.2307/2065853

Fornell, C., \& Larcker, D. F. (1981). Evaluating Structural Equation Models with Unobservable Variables and Measurement Error. JMR, Journal of Marketing Research, 18(1), 39-50. doi:10.1177/002224378101800104

Ghazali, E., Soon, P. C., Mutum, D. S., \& Nguyen, B. (2017). Health and cosmetics: Investigating consumers' values for buying organic personal care products. Journal of Retailing and Consumer Services, 39(39), 154-163. doi:10.1016/j.jretconser.2017.08.002 
Goldsmith, R. E. (2002). Explaining and Predicting Consumer Intention to Purchase Over the Internet: An Exploratory Study. Journal of Marketing Theory and Practice, 10(2), 22-28. doi:10.1080/10696679.2002.11 501913

Gu, J.-C., Lee, S.-C., \& Suh, Y.-H. (2009). Determinants of behavioral intention to mobile banking. Expert Systems with Applications, 36(9), 11605-11616. doi:10.1016/j.eswa.2009.03.024

Hair, J., Hult, G. T., Ringle, C., \& Sarstedt, M. (2014). A Primer on Partial Least Squares Structural Equation Modeling (PLS-SEM). 2014 Faculty Bookshelf. https://digitalcommons.kennesaw.edu/facbooks2014/39/

Halaweh, M., \& Al Qaisi, H. (2016). Adoption of Near Field Communication (NFC) for Mobile Payments in the UAE. International Journal of E-Business Research, 12(4), 38-56. doi:10.4018/IJEBR.2016100103

Hansen, T., Risborg, M. S., \& Steen, C. D. (2012). Understanding consumer purchase of free-of cosmetics: A value-driven TRA approach. Journal of Consumer Behaviour, 11(6), 477-486. doi:10.1002/cb.1397

Hart, C. W. (2020). Spiritual Lessons From the Coronavirus Pandemic. Journal of Religion and Health, 59(2), 623-624. doi:10.1007/s10943-020-01011-w PMID:32219671

Hew, J.-J., Tan, G. W.-H., Lin, B., \& Ooi, K.-B. (2017). Generating travel-related contents through mobile social tourism: Does privacy paradox persist? Telematics and Informatics, 34(7), 914-935. doi:10.1016/j. tele.2017.04.001

Ho Cheong, J., \& Park, M. (2005). Mobile internet acceptance in Korea. Internet Research, 15(2), $125-140$. doi:10.1108/10662240510590324

Humbani, M., \& Wiese, M. (2017). A Cashless Society for All: Determining Consumers' Readiness to Adopt Mobile Payment Services. Journal of African Business, 19(3), 409-429. doi:10.1080/15228916.2017.1396792

Inman, J. J., \& Nikolova, H. (2017). Shopper-Facing Retail Technology: A Retailer Adoption Decision Framework Incorporating Shopper Attitudes and Privacy Concerns. Journal of Retailing, 93(1), 7-28. doi:10.1016/j. jretai.2016.12.006

Kaatz, C. (2020). Retail in my pocket- replicating and extending the construct of service quality into the mobile commerce context. Journal of Retailing and Consumer Services, 53(101983), 101983. doi:10.1016/j. jretconser.2019.101983

Kamal, S. A., Shafiq, M., \& Kakria, P. (2020). Investigating acceptance of telemedicine services through an extended technology acceptance model (TAM). Technology in Society, 60, 101212. doi:10.1016/j. techsoc.2019.101212

Kim, C., Mirusmonov, M., \& Lee, I. (2010). An empirical examination of factors influencing the intention to use mobile payment. Computers in Human Behavior, 26(3), 310-322. doi:10.1016/j.chb.2009.10.013

Kock, N., \& Hadaya, P. (2018). Minimum sample size estimation in PLS-SEM: The inverse square root and gamma-exponential methods. Journal of Information Systems, 28(1), 227-261. doi:10.1111/isj.12131

Kumar, A., \& Mukherjee, A. (2013). Shop while you talk: Determinants of purchase intentions through a mobile device. International Journal of Mobile Marketing, 8(1), 23-37.

Lam, S. Y., Chiang, J., \& Parasuraman, A. (2008). The effects of the dimensions of technology readiness on technology acceptance: An empirical analysis. Journal of Interactive Marketing, 22(4), 19-39. doi:10.1002/ $\operatorname{dir} .20119$

Lee, D. Y., \& Ryu, H. (2013). Learner Acceptance of a Multimedia-Based Learning System. International Journal of Human-Computer Interaction, 29(6), 419-437. doi:10.1080/10447318.2012.715278

Legris, P., Ingham, J., \& Collerette, P. (2003). Why do people use information technology? A critical review of the technology acceptance model. Information \& Management, 40(3), 191-204. doi:10.1016/S0378-7206(01)00143-4

Leong, L.-Y., Hew, T.-S., Tan, G. W.-H., \& Ooi, K.-B. (2013). Predicting the determinants of the NFC-enabled mobile credit card acceptance: A neural networks approach. Expert Systems with Applications, 40(14), 5604-5620. doi:10.1016/j.eswa.2013.04.018 
Liébana-Cabanillas, F. (2012). El papel de los sistemas de pago en los nuevos entornos electrónicos (PhD Thesis). Department of Marketing and Market Research. Universidad de Granada.

Limayem, M., Khalifa, M., \& Frini, A. (2000). What makes consumers buy from Internet? A longitudinal study of online shopping. IEEE Transactions on Systems, Man, and Cybernetics. Part A, Systems and Humans, 30(4), 421-432. doi:10.1109/3468.852436

Lindell, M. K., \& Whitney, D. J. (2001). Accounting for common method variance in cross-sectional research designs. The Journal of Applied Psychology, 86(1), 114-121. doi:10.1037/0021-9010.86.1.114 PMID:11302223

Loh, X.-M., Lee, V.-H., Tan, G. W.-H., Hew, J.-J., \& Ooi, K.-B. (2019). Towards a Cashless Society: The Imminent Role of Wearable Technology. Journal of Computer Information Systems, 1-11. doi:10.1080/08874 417.2019.1688733

Lu, Y., Cao, Y., Wang, B., \& Yang, S. (2011). A study on factors that affect users' behavioral intention to transfer usage from the offline to the online channel. Computers in Human Behavior, 27(1), 355-364. doi:10.1016/j. chb.2010.08.013

Luarn, P., \& Lin, H.-H. (2005). Toward an understanding of the behavioral intention to use mobile banking. Computers in Human Behavior, 21(6), 873-891. doi:10.1016/j.chb.2004.03.003

Makki, A. M., Ozturk, A. B., \& Singh, D. (2016). Role of risk, self-efficacy, and innovativeness on behavioral intentions for mobile payment systems in the restaurant industry. Journal of Foodservice Business Research, 19(5), 454-473. doi:10.1080/15378020.2016.1188646

Mallat, N. (2007). Exploring consumer adoption of mobile payments - A qualitative study. The Journal of Strategic Information Systems, 16(4), 413-432. doi:10.1016/j.jsis.2007.08.001

Manochehri, N.-N., \& AlHinai, Y. S. (2008). Mobile-phone users' attitudes towards' mobile commerce \& services in the Gulf Cooperation Council countries: Case study. 2008 International Conference on Service Systems and Service Management. doi:10.1109/ICSSSM.2008.4598475

Meharia, P. (2012). Assurance on the reliability of mobile payment system and its effects on its' use: An empirical examination. Accounting and Management Information Systems, 11(1), 97-111. http://online-cig.ase.ro/RePEc/ ami/articles/11_1_6.pdf

Musa, A., Khan, H. U., \& AlShare, K. A. (2015). Factors influence consumers' adoption of mobile payment devices in Qatar. International Journal of Mobile Communications, 13(6), 670. doi:10.1504/IJMC.2015.072100

Nielsen. (2019). Cash or cashless? Malaysia's shifting payment landscape. https://www.nielsen.com/my/en/ insights/article/2019/cash-or-cashless-malaysias-shifting-payment-landscape/

Nysveen, H. (2005). Intentions to Use Mobile Services: Antecedents and Cross-Service Comparisons. Journal of the Academy of Marketing Science, 33(3), 330-346. doi:10.1177/0092070305276149

Oh, J. C., Yoon, S. J., \& Chung, N. (2014). The role of technology readiness in consumers' adoption of mobile internet services between South Korea and China. International Journal of Mobile Communications, 12(3), 229. doi:10.1504/IJMC.2014.061460

Oliveira, T., Thomas, M., Baptista, G., \& Campos, F. (2016). Mobile payment: Understanding the determinants of customer adoption and intention to recommend the technology. Computers in Human Behavior, 61(61), 404-414. doi:10.1016/j.chb.2016.03.030

Ong, C.-S., Lai, J.-Y., \& Wang, Y.-S. (2004). Factors affecting engineers' acceptance of asynchronous e-learning systems in high-tech companies. Information \& Management, 41(6), 795-804. doi:10.1016/j.im.2003.08.012

Ooi, K.-B., Sim, J.-J., Yew, K.-T., \& Lin, B. (2011). Exploring factors influencing consumers' behavioral intention to adopt broadband in Malaysia. Computers in Human Behavior, 27(3), 1168-1178. doi:10.1016/j. chb.2010.12.011

Ooi, K.-B., \& Tan, G. W.-H. (2016). Mobile technology acceptance model: An investigation using mobile users to explore smartphone credit card. Expert Systems with Applications, 59, 33-46. doi:10.1016/j.eswa.2016.04.015

Parasuraman, A. (2000). Technology Readiness Index (Tri). Journal of Service Research, 2(4), 307-320. doi:10.1177/109467050024001 
Parasuraman, A., \& Colby, C. L. (2014). An Updated and Streamlined Technology Readiness Index. Journal of Service Research, 18(1), 59-74. doi:10.1177/1094670514539730

Pavlou, P. A. (2002). Institution-based trust in interorganizational exchange relationships: The role of online B2B marketplaces on trust formation. The Journal of Strategic Information Systems, 11(3-4), 215-243. doi:10.1016/ S0963-8687(02)00017-3

Pavlou, P. A. (2003). Consumer Acceptance of Electronic Commerce: Integrating Trust and Risk with the Technology Acceptance Model. International Journal of Electronic Commerce, 7(3), 101-134. doi:10.1080/1 0864415.2003 .11044275

Phan, K., \& Daim, T. (2011). Exploring technology acceptance for mobile services. Journal of Industrial Engineering and Management, 4(2), 339-360. doi:10.3926/jiem.2011.v4n2.p339-360

Pillai, R., Sivathanu, B., \& Dwivedi, Y. K. (2020). Shopping intention at AI-powered automated retail stores (AIPARS). Journal of Retailing and Consumer Services, 57(102207), 102207. doi:10.1016/j. jretconser.2020.102207

Podsakoff, P. M., MacKenzie, S. B., Lee, J.-Y., \& Podsakoff, N. P. (2003). Common method biases in behavioral research: A critical review of the literature and recommended remedies. The Journal of Applied Psychology, 88(5), 879-903. doi:10.1037/0021-9010.88.5.879 PMID:14516251

Rampton, J. (2017, April 4). How Digital Wallets and Mobile Payments Are Evolving and What It Means for You. Entrepreneur. https://www.entrepreneur.com/article/292256

Rouibah, K. (2007). Does mobile payment technology Mnet attract potential consumers? The case of Kuwait. ACIS 2007 Proceedings, 24.

Rouibah, K. (2009). The failure of mobile payment: Evidence from quasi-experimentations. Proceedings of the 2009 Euro American Conference on Telematics and Information Systems: New Opportunities to Increase Digital Citizenship, 29.

Saudi Arabia grants kingdom's first digital banking licences. (2021, June 24). FinTech Futures. https://www. fintechfutures.com/2021/06/saudi-arabia-grants-first-digital-banking-licences/

Schierz, P. G., Schilke, O., \& Wirtz, B. W. (2010). Understanding consumer acceptance of mobile payment services: An empirical analysis. Electronic Commerce Research and Applications, 9(3), 209-216. doi:10.1016/j. elerap.2009.07.005

Sekaran, U., \& Bougie, R. (2016). Research Methods for Business: a Skill-Building Approach. John Wiley \& Sons.

Shaikh, A. A., Alharthi, M. D., \& Alamoudi, H. O. (2020). Examining key drivers of consumer experience with (non-financial) digital services-An exploratory study. Journal of Retailing and Consumer Services, 55, 102073. doi:10.1016/j.jretconser.2020.102073

Sharma, S. K., Govindaluri, S. M., \& Al Balushi, S. M. (2015). Predicting determinants of Internet banking adoption. Management Research Review, 38(7), 750-766. doi:10.1108/MRR-06-2014-0139

Sharma, S. K., Sharma, H., \& Dwivedi, Y. K. (2019). A Hybrid SEM-Neural Network Model for Predicting Determinants of Mobile Payment Services. Information Systems Management, 36(3), 243-261. doi:10.1080/1 0580530.2019 .1620504

Shih, Y., \& Fang, K. (2004). The use of a decomposed theory of planned behavior to study Internet banking in Taiwan. Internet Research, 14(3), 213-223. doi:10.1108/10662240410542643

Shin, S., \& Lee, W. (2014). The Effects Of Technology Readiness And Technology Acceptance On Nfc Mobile Payment Services In Korea. Journal of Applied Business Research, 30(6), 1615. doi:10.19030/jabr.v30i6.8873

Slade, E. L., Dwivedi, Y. K., Piercy, N. C., \& Williams, M. D. (2015). Modeling Consumers’ Adoption Intentions of Remote Mobile Payments in the United Kingdom: Extending UTAUT with Innovativeness, Risk, and Trust. Psychology and Marketing, 32(8), 860-873. doi:10.1002/mar.20823

Slade, E. L., Williams, M. D., \& Dwivedi, Y. K. (2013). Mobile payment adoption: Classification and review of the extant literature. The Marketing Review, 13(2), 167-190. doi:10.1362/146934713X13699019904687 
Soomro, Y. A. (2019). Understanding the Adoption of SADAD E-Payments. International Journal of E-Business Research, 15(1), 55-74. doi:10.4018/IJEBR.2019010104

Sustainable consumption and production. (2021). United Nations Sustainable Development. Retrieved 14 August 2021, from https://www.un.org/sustainabledevelopment/sustainable-consumption-production/

Tan, G. W.-H., \& Ooi, K.-B. (2018). Gender and age: Do they really moderate mobile tourism shopping behavior? Telematics and Informatics, 35(6), 1617-1642. doi:10.1016/j.tele.2018.04.009

Tan, G. W.-H., Ooi, K.-B., Chong, S.-C., \& Hew, T.-S. (2014). NFC mobile credit card: The next frontier of mobile payment? Telematics and Informatics, 31(2), 292-307. doi:10.1016/j.tele.2013.06.002

Teo, A.-C., Tan, G. W.-H., Ooi, K.-B., Hew, T.-S., \& Yew, K.-T. (2015). The effects of convenience and speed in m-payment. Industrial Management \& Data Systems, 115(2), 311-331. doi:10.1108/IMDS-08-2014-0231

Tsai, C.-H., Zhu, D.-S., Ho, B. C.-T., \& Wu, D. D. (2010). The effect of reducing risk and improving personal motivation on the adoption of knowledge repository system. Technological Forecasting and Social Change, 77(6), 840-856. doi:10.1016/j.techfore.2010.01.011

van der Heijden, H., Verhagen, T., \& Creemers, M. (2003). Understanding online purchase intentions: Contributions from technology and trust perspectives. European Journal of Information Systems, 12(1), 41-48. doi:10.1057/palgrave.ejis.3000445

Venkatesh, V., \& Davis, F. D. (2000). A Theoretical Extension of the Technology Acceptance Model: Four Longitudinal Field Studies. Management Science, 46(2), 186-204. doi:10.1287/mnsc.46.2.186.11926

Venkatesh, V., Thong, J. Y. L., \& Xu, X. (2012). Consumer Acceptance and Use of Information Technology: Extending the Unified Theory of Acceptance and Use of Technology. Management Information Systems Quarterly, 36(1), 157. doi:10.2307/41410412

Vijayasarathy, L. R. (2004). Predicting consumer intentions to use on-line shopping: The case for an augmented technology acceptance model. Information \& Management, 41(6), 747-762. doi:10.1016/j.im.2003.08.011

Walker, H. (n.d.). Shoppers have an appetite for smart retail tech - but they're picky. The Grocer. Retrieved August 14, 2021, from https://www.thegrocer.co.uk/online/shoppers-have-an-appetite-for-smart-retail-tech-buttheyre-picky-/571208.article

Wang, Y., Wang, Y., Lin, H., \& Tang, T. (2003). Determinants of user acceptance of Internet banking: An empirical study. International Journal of Service Industry Management, 14(5), 501-519. doi:10.1108/09564230310500192

Wilder-Smith, A., Chiew, C. J., \& Lee, V. J. (2020). Can we contain the COVID-19 outbreak with the same measures as for SARS? The Lancet. Infectious Diseases, 20(5), e102-e107. Advance online publication. doi:10.1016/S1473-3099(20)30129-8 PMID:32145768

Wilson Vanvoorhis, C., \& Morgan, B. (2007). Understanding Power and Rules of Thumb for Determining Sample Sizes. Tutorials in Quantitative Methods for Psychology, 3(2), 43-50. https://www.tqmp.org/RegularArticles/ vol03-2/p043/p043.pdf. doi:10.20982/tqmp.03.2.p043

Wong, C.-H., Tan, G. W.-H., Loke, S.-P., \& Ooi, K.-B. (2015). Adoption of mobile social networking sites for learning? Online Information Review, 39(6), 762-778. doi:10.1108/OIR-05-2015-0152

Yan, L.-Y., Tan, G. W.-H., Loh, X.-M., Hew, J.-J., \& Ooi, K.-B. (2021). QR code and mobile payment: The disruptive forces in retail. Journal of Retailing and Consumer Services, 58(102300), 102300. doi:10.1016/j. jretconser.2020.102300

Yang, K. (2010). Determinants of US consumer mobile shopping services adoption: Implications for designing mobile shopping services. Journal of Consumer Marketing, 27(3), 262-270. doi:10.1108/07363761011038338

Yang, K. (2012). Consumer technology traits in determining mobile shopping adoption: An application of the extended theory of planned behavior. Journal of Retailing and Consumer Services, 19(5), 484-491. doi:10.1016/j. jretconser.2012.06.003

Yang, K. C. C. (2005). Exploring factors affecting the adoption of mobile commerce in Singapore. Telematics and Informatics, 22(3), 257-277. doi:10.1016/j.tele.2004.11.003 
Zarmpou, T., Saprikis, V., Markos, A., \& Vlachopoulou, M. (2012). Modeling users' acceptance of mobile services. Electronic Commerce Research, 12(2), 225-248. doi:10.1007/s10660-012-9092-x

Zhang, J., \& Wedel, M. (2009). The Effectiveness of Customized Promotions in Online and Offline Stores. JMR, Journal of Marketing Research, 46(2), 190-206. doi:10.1509/jmkr.46.2.190

Zhang, Y., Sun, J., Yang, Z., \& Wang, Y. (2018). What Makes People Actually Embrace or Shun Mobile Payment: A Cross-Culture Study. Mobile Information Systems, 2018, 1-13. doi:10.1155/2018/7497545 